\title{
Halogen heterogeneity in the Icelandic mantle source
}

\author{
E. C. WATERS ${ }^{1 *}$, M. E. Hartley ${ }^{1}$, R. Burgess ${ }^{1}$, A. \\ PAWLEY $^{1}$, S. A. HALldóRSSON ${ }^{2}$, O. ShORTTLE ${ }^{3}$ \\ ${ }^{1}$ Department of Earth and Environmental Sciences, University \\ of Manchester, U.K. (*correspondence: \\ emma.waters@manchester.ac.uk) \\ ${ }^{2}$ NordVulk, Institute of Earth Sciences, University of Iceland \\ ${ }^{3}$ Department of Earth Sciences, University of Cambridge
}

The Icelandic mantle displays a great degree of heterogeneity with primordial domains, depleted domains and a component(s) of recycled crust. The spatial distribution of this recycled component(s) is poorly constrained, but is proposed to contribute $4-10 \%$ of the Icelandic mantle [1].

Fluid-mobile halogens $(\mathrm{F}, \mathrm{Cl}, \mathrm{Br}, \mathrm{I})$ are concentrated in subducting slabs, making them powerful tracers of recycled material in the mantle. Nominally anhydrous minerals in dehydrated slab residues may store small quantities of halogens [2] which may be transported to the deep mantle.

To determine the halogen content of Iceland's different mantle domains we have analysed olivine- and plagioclasehosted melt inclusions from glassy sub-glacial pillow lavas from three field areas. Miðfell, in Iceland's Western Volcanic Zone, samples both depleted and primordial mantle components [3]. Snæfellsjökull, far from the plume centre, erupts enriched alkali basalts, possibly sampling recycled material. Oræfajökull erupts enriched melts in another flank zone slightly closer to the plume. Melt inclusion analyses from these three localities constrain both short-wavelength heterogeneity, as well as long-wavelength 'plume-like' and 'non-plume-like' sources in the Icelandic mantle.

We present major and trace element, $\mathrm{F}$ and $\mathrm{Cl}$ compositions of melt inclusions from the three sites. Both flank zone localities, Snæfellsjökull (471-1152 ppm F, 428796 ppm Cl) and Oræfajökull (275-348 ppm F, 274-350 ppm $\mathrm{Cl}$ ), show greater $\mathrm{F}$ and $\mathrm{Cl}$ concentrations than Miðfell (3$135 \mathrm{ppm} \mathrm{F}$, 3-236 ppm Cl). The flank zones have OIB compositions and have HIMU (Snæfellsjökull) and EM1 (Oræfajökull) affinities based on their incompatible trace element and halogen/trace element ratios. Significant heterogeneity in Miðfell melt inclusions $(\mathrm{F} / \mathrm{Pr}=114.1 \pm 75.9$ $1 \sigma, \quad \mathrm{Cl} / \mathrm{K}=0.078 \pm 0.0121 \sigma)$ requires short-wavelength mantle heterogeneity, with at least three distinct mantle domains. We utilise halogen/ trace element ratios to investigate if recycled halogens are distributed throughout the mantle or entrained in the deep-seated mantle plume.

[1] Shorttle et al. (2014). EPSL 395, 24-40. [2] Kendrick et al. (2011) Nature Geosciences 4(11), 807-812. [3] Mukhopadhyay (2012) Nature 486, 101-106. 